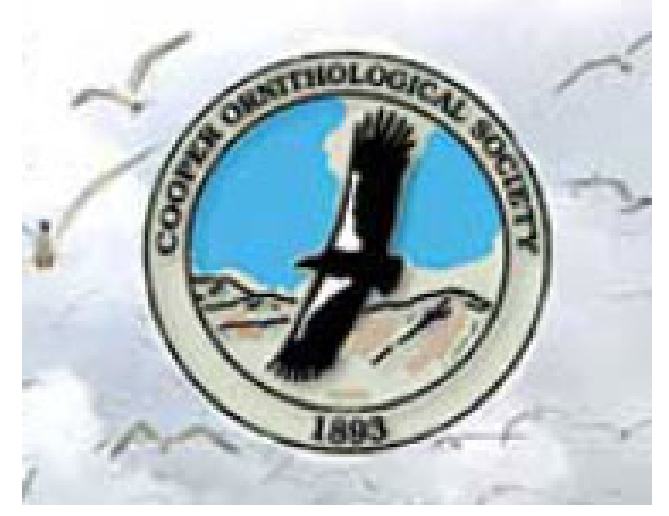

Post-Fledging Broods of Migratory Harlequin Ducks Accompany Females to Wintering Areas Author(s): Heidi M. Regehr, Cyndi M. Smith, Brian Arquilla, Fred Cooke

Reviewed work(s):

Source: The Condor, Vol. 103, No. 2 (May, 2001), pp. 408-412

Published by: University of California Press on behalf of the Cooper Ornithological Society

Stable URL: http://www.jstor.org/stable/1370392

Accessed: 23/04/2012 15:23

Your use of the JSTOR archive indicates your acceptance of the Terms \& Conditions of Use, available at http://www.jstor.org/page/info/about/policies/terms.jsp

JSTOR is a not-for-profit service that helps scholars, researchers, and students discover, use, and build upon a wide range of content in a trusted digital archive. We use information technology and tools to increase productivity and facilitate new forms of scholarship. For more information about JSTOR, please contact support@jstor.org. 
ance responses of a host species, the Red-footed Booby. Condor 99:162-168.

Le Corre, M., AND P. Jouventin. 1997b. Ecological significance and conservation priorities of Europa Island (western Indian Ocean), with special reference to seabirds. Terre et Vie 52:205-220.

LE GALL, J. Y. 1988. Biologie et évaluation des populations de Tortue Verte Chelonia mydas des atolls Tromelin et Europa (océan indien S.O.). Mésogée 48:33-42.

Le Gall, J. Y., P. Bosc, D. Château, and M. Taquet. 1986. Estimation du nombre de Tortues Vertes femelles adultes Chelonia mydas par saison de ponte à Tromelin et Europa (océan indien) (19731985). Océanographie Tropicale 21:3-22.

Le Gall, J. Y., A. LebeAU, AND J. KopP. 1985. Evaluation de la production de Tortues Vertes Chelonia mydas nouveau-nées sur les sites de ponte Europa et Tromelin (océan indien). Océanographie Tropicale 20:117-133.

Marchant, S., AND P. J. Higgins. 1990. Handbook of Australian, New Zealand and Antarctic birds. Vol. 1. Oxford University Press, Oxford, UK.

MEGYESI, J. L., AND C. R. GRIFFIN. 1996. Brown Noddy chick predation by Great Frigatebirds in the northwestern Hawaiian islands. Condor 98:322-327.

MiLleR, J. D. 1996. Reproduction in sea turtles, p. 5181. In P. L. Lutz and J. A. Musick [EDS.], The biology of sea turtles. Marine Science Series. C.R.C. Press, Boca Raton, FL.

MuEller, H. C. 1990. The evolution of reversed sexual dimorphism in size in monogamous species of birds. Biological Review 65:553-585.

NeLSON, J. B. 1975. The breeding biology of frigatebirds: a comparative review. Living Bird 14:113156.
Nelson, J. B. 1983. Contrast in breeding strategies between some tropical and temperate marine Pelecaniformes. Studies in Avian Biology 8:95-114.

NiEthammer, K. R., G. H. Balazs, G. L. NAKAI, AND D. K. MCDERmond. 1992. Great Frigatebird (Fregata minor) predation: not a factor in hatchling Green Turtle (Chelonia mydas) survival at French Frigate Shoals, Hawaii. Colonial Waterbirds 15: $128-131$.

ORTA, J. O. 1992. Fregatidae, p. 912-934. In J. Del Hoyo and J. Sargatal [EDS.], Handbook of the birds of the world. Vol. 1. Lynx edicions, Barcelona.

Osorno, J. L., R. Torres, and C. Macias Garcia. 1992. Kleptoparasitic behavior of the Magnificent Frigatebird: sex bias and success. Condor 94:692698.

SChreiber, R. W., AND R. B. ClapP. 1987. Pelecaniform feeding ecology, p. 173-188. In J. P. Croxall [ED.], Seabirds: feeding ecology and role in marine ecosystems. Cambridge University Press, Cambridge, UK.

SERVAN J. 1976. Ecologie de la tortue verte à l'île d'Europa (canal du Mozambique). Terre and Vie 30:421-464.

Statsoft INC. 1997. Statistica user's guide. Version 5.1. Statsoft Inc., Tulsa, OK.

STANCYK, S. E. 1982. Non-human predators of sea turtles and their control, p. 139-152. In K. A. Bjorndal [ED.], Biology and conservation of sea turtles. Smithsonian Institution Press, Washington, DC.

Vickery, J. A., AND B. M. DE L. Brooke. 1994. The kleptoparasitic interactions between Great Frigatebirds and Masked Boobies on Henderson Island, South Pacific. Condor 96:331-340.

\title{
POST-FLEDGING BROODS OF MIGRATORY HARLEQUIN DUCKS ACCOMPANY FEMALES TO WINTERING AREAS ${ }^{1}$
}

\author{
Heidi M. Regehr, ${ }^{2}$ Cyndi M. Smith,${ }^{3}$ Brian Arquilla and Fred CoOKe \\ Department of Biological Sciences, Simon Fraser University, Burnaby, BC V5A 1S6, Canada
}

Abstract. We describe evidence that Harlequin Duck (Histrionicus histrionicus) broods accompany their mothers from breeding streams to coastal molting

\footnotetext{
${ }^{1}$ Received 19 July 2000. Accepted 15 January 2001.

${ }^{2}$ E-mail: hmregehr@sfu.ca

${ }^{3}$ Present address: Parks Canada, Box 900, Banff, AB TOL 0C0, Canada.
}

or wintering areas. Observations indicated that all surviving female-offspring groups left breeding areas together. We later sighted some family members at the coast near each other, suggesting that they had arrived together, then separated. We observed family groups at wintering areas in August and September. Family groups tended to separate quickly, although some family members maintained contact for over five months. To our knowledge the evidence we provide is the first 
suggesting that female migratory ducks bring their offspring to wintering areas, a pattern similar to geese and swans. This may be facilitated by an unusual strategy of wing molt, in which Harlequin Ducks molt after migrating to wintering areas. Due to winter pairing and strong philopatry in Harlequin Ducks, migration of families may contribute to genetic differentiation among populations.

Key words: brood abandonment, Harlequin Duck, Histrionicus histrionicus, migration, parental care, population structure.

\section{Los Juveniles de Histrionicus histrionicus Migratorios Acompañan a las Hembras a las Áreas de Invernada}

Resumen. Presentamos evidencia de que los juveniles de Histrionicus histrionicus acompañan a sus madres desde los arroyos de reproducción hasta las áreas costeras de muda o invernada. Las observaciones indicaron que todos los grupos sobrevivientes de hembras y crías abandonaron juntos las áreas de reproducción. Más adelante observamos algunos miembros de grupos familiares cerca unos de otros en la costa, sugiriendo que habían llegado juntos y luego se habían separado. Observamos grupos familiares en las áreas de invernada en agosto y septiembre. Los grupos familiares tendieron a separarse rápidamente, aunque algunos miembros mantuvieron contacto por más de cinco meses. A nuestro entender, esta es la primera evidencia de que las hembras de patos migratorios llevan a sus crías a los sitios de invernada, un patrón similar al de los gansos y cisnes. Esto podría ser facilitado por una estrategia poco usual, en la que $H$. histrionicus muda las plumas de las alas después de migrar hacia las áreas de invernada. Debido a la formación de parejas en invierno y a la fuerte filopatría en $H$. histrionicus, la migración de familias podría contribuir a la diferenciación genética entre poblaciones.

The age at which juveniles separate from their parents can be predicted from theories of parent-offspring conflict (Carlisle 1982). Parents should abandon their young when prospects for future fitness through abandonment are greater than fitness gained from attending the present brood. Among waterfowl there are two broad patterns of brood abandonment. In swans and geese (Anserini), which have long-term pair bonds, juveniles generally accompany both parents throughout the first year of life, staying with them during both migratory journeys between breeding and wintering grounds (Prevett and MacInnes 1980). In contrast, in seasonally monogamous ducks (Anatini, Aythyini, Mergini), males of migratory species abandon their mates, usually before young hatch, while females accompany their young for a variable period but typically are thought to leave them prior to fledging (Afton and Paulus 1992, Eadie et al. 1995, Mallory and Metz 1999).

Timing of brood abandonment is presumably an optimization of costs and benefits, which may vary with brood size and age, female condition, and other life history variables. Parental care enhances brood surviv- al, particularly early in the lives of the offspring, through brooding, protection from predators, aiding in competitive interactions, finding suitable habitats, guiding offspring during migration, and helping them locate staging and wintering grounds. Conversely, caring for young may be costly for females because it may reduce their foraging time and they may suffer increased mortality risk while defending the young (Afton and Paulus 1992).

We examined the timing of brood abandonment by Harlequin Ducks (Histrionicus histrionicus). They have long-term pair bonds in common with Anserini, and uniparental care in common with the ducks. Some previous studies have suggested that females may abandon their broods prior to fledging (Wallen 1987, Cassirer and Groves 1991, Diamond and Finnegan 1993, Reichel et al. 1997), while others have suggested that they are still with their broods at fledging (Bengtson 1966, Kuchel 1977). There are anecdotal accounts of family groups at great distances from suitable breeding streams (Cooke et al. 2000). Research at both breeding and wintering areas of part of the Pacific population allowed us to investigate the departure of juveniles and family groups from breeding streams and their subsequent arrival and behavior at coastal wintering areas.

\section{METHODS}

We conducted the breeding-season portion of this study from May to September, 1996 to 1998, on the Bow, Elbow, Highwood, and Kananaskis Rivers, and Smith-Dorrien Creek, in southwestern Alberta, Canada. We conducted observations at coastal wintering areas from 1997 to 2000 at Hornby Island, the Cape Lazo area of eastern Vancouver Island (between Comox and Campbell River), and White Rock, British Columbia, Canada, and at Birch Bay and Point Roberts, Washington, USA.

On breeding streams we used mist nets to capture Harlequin Duck females with other adults in May and with flightless broods in August and September. We marked each bird with a USFWS tarsal band and a uniquely engraved colored plastic band. In 1997 and 1998, 16 females and their broods received either intra-abdominal transmitters with external whip antennae, or external transmitters, attached mid-dorsally with subdermal wire anchors and sutures. We monitored these families at least once per week until migration or mortality, then made telemetry flights over the Strait of Georgia, British Columbia, using fixedwing aircraft during winter 1997-1998 and October 1999.

On wintering areas, we surveyed White Rock once per week in 1997, two to three times per week in 1998 and 1999, and opportunistically in 2000 . We surveyed Birch Bay and Point Roberts once every two weeks in 1999, Hornby Island from 8 to 13 September 1999 and from 10 to 15 September 2000, and the Cape Lazo area from 14 to 18 September 1999 and from 29 August to 8 September 2000. Many birds were identifiable by unique tarsal bands or nasal disks from previous banding operations. Juveniles were separable from adults by finely vermiculated plumage on the breast, belly, and 
vent, mottled yellow and gray legs and feet, dusky faces, and occasionally, notched tail feathers.

On wintering areas, we defined a "family" as an association between one adult female and one or more juveniles in which the adult female had full old primaries, indicating recent arrival, and assumed a leading or vigilant role. To avoid duplicate recording of families, we report separate families only if they were seen' concurrently, were separated in time by at least 10 days (this is the average time to the loss of primaries, FC unpubl. data), or if females were identified.

We recorded composition of all Harlequin Duck groups to determine the frequency of family groups and the social choices of juveniles in all locations in 1999 and at Hornby Island and Cape Lazo in 2000. We defined a group as one or more individuals separated from others by at least $10 \mathrm{~m}$. Surveys conducted at the same location on different days may have included juveniles sampled on previous days. We did not attempt to correct for duplicate sightings, but conducted only one survey in any location on any day.

We captured three family groups, one at Cape Lazo in 1999, and one each at Cape Lazo and Hornby Island in 2000 (families had four, four, and two juveniles, respectively) using mist nets and decoys. We marked all individuals with tarsal bands and nasal disks in both years, and with external radio transmitters in 2000 . We conducted 10-min to 2-hr behavioral observations on the two families marked at Cape Lazo on four and five occasions in 1999 and 2000, respectively. We observed both juveniles from the family at Hornby Island on three occasions one and two days following capture; both died shortly thereafter. During observations we recorded the relative locations and social interactions of family members.

\section{RESULTS}

We were able to monitor the fates of 15 families that were radio-marked at breeding areas. No female abandoned her brood prior to migration from the breeding stream. When both the female and her brood survived (three cases), the entire family departed at the same time. For the remaining females, either the female died (five cases) or the brood died (seven cases).

We observed two cases of at least temporary adoption on the breeding streams. One female added a duckling to her brood of 6 for at least 14 days. One duckling whose mother died joined a female that had lost her brood and appeared to migrate with her, as both disappeared from the stream at the same time. We also observed one case of brood amalgamation and one case of at least temporary brood mixing.

At wintering areas we resighted two families that had been marked at the breeding streams. Family members were sighted in the same general area (within $15 \mathrm{~km}$ ), but were not observed to associate with each other.

We observed 25 different Harlequin Duck families at wintering areas from 22 August to 26 September in four years. Females were seen with one $(n=5)$, two $(n=8)$, three $(n=3)$, four $(n=4)$, five $(n=1)$, six $(n=3)$, and seven $(n=1)$ juveniles. Four previously banded females were seen in family groups at White Rock, and all were with juveniles when they were first observed at the site that season. We also observed one family-like association that was clearly not a family group: one female with four juveniles was a banded yearling that had been in the area throughout the year.

Most families separated shortly after arrival at wintering areas, but some individuals maintained contact for at least five months. Previously banded females seen with juveniles were without them 9 to 46 days after the initial family sighting. All adult females captured in family groups were resighted with at least some of the juveniles captured with them. Only two juveniles from the family captured in 1999 remained with the adult female one day after capture, one remained after two days, and none remained after a month. The female from the family captured at Cape Lazo in 2000 was $2 \mathrm{~km}$ from the juveniles one day after capture, but all family members were together again after 13 days, and all were within $1 \mathrm{~km}$ of each other after 42 days. After 73 days, the female and two juveniles were together, the third juvenile was $2 \mathrm{~km}$ away, and the fourth had died. Observations of the marked families suggested that the females did not act aggressively toward the juveniles, but interacted with them and defended them from other adults.

We observed juveniles in a variety of group compositions. Of 161 coastal juvenile sightings, juveniles were solitary ( 21 times), in the company of other juveniles only ( 24 times), in the company of non-vigilant or newly molted females only (23 times), in the company of adult males only (21 times), with a mix of adult males and females (44 times), and in family groups (28 times).

\section{DISCUSSION}

Our study provides evidence that Harlequin Duck broods accompany females from breeding to wintering areas. Three entire families departed from breeding streams after the young fledged, and some family members were subsequently sighted near each other on wintering areas, an observation that would be unlikely if they had migrated independently to the coast. Observations on wintering areas indicated that family-like groupings appeared, then generally separated rapidly; hence most juveniles were not seen in family groups but in a wide range of social associations. Thus, although some juveniles may arrive at the coast alone or in sibling groups without their mothers, the presence of juveniles on the coast without females is not proof that they arrived alone (cf. Robertson and Goudie 1999). Our results suggest that most females accompany their young and that most family groups separate soon after arrival at the coast, although some family members may associate for several months.

Although we cannot be certain that the associations observed at wintering areas were true families, we think that most were for several reasons: (1) no radio-marked female abandoned her brood on the breeding stream, (2) behavior of coastal family-like groups was indistinguishable from that of known post-fledging families in breeding areas, (3) family-like groups that were captured and marked continued to associate afterwards, (4) group size was similar to expected family size, given high juvenile mortality (Smith 2000), and (5) arrival of females with young in wintering areas coincided with the time expected for successful nesters (Smith et al. 2000). Clearly 
some family-like groups were unrelated, because we observed one group that could not have been a true family, and adoption and brood amalgamation in breeding areas has been observed in this and in other studies (Bengston 1966, Rodway et al. 1998).

The arrival of entire families at wintering areas has implications for population genetic structure, demographics, and conservation. If juveniles arrive at the molting or wintering area of their mothers, then they may find themselves in the same wintering locations as their siblings from multiple breeding seasons, given high site fidelity of females to molting and wintering sites (Breault and Savard 1999, Robertson et al. 1999). Due to winter pairing in Harlequin Ducks, this could lead to local wintering populations becoming more genetically similar over time, which could lead to genetically differentiated populations, something that is thought to be rare in migratory ducks (Anderson et al. 1992). Additionally, if all recruitment to local wintering populations comes from specific groups of birds, recovery from local population reductions could be slow.

In breeding areas, we observed death of the mother, adoption, brood amalgamation, and brood mixing, all of which could result in juvenile migration from breeding to wintering areas alone or with a female that is not its biological parent. Such juveniles are unlikely to migrate to their mother's molting or wintering location because coastal wintering habitat is extensive and individuals breeding in proximity can migrate to widely separated wintering sites (Regehr et al., unpubl. data). Juveniles departing alone or with an adoptive parent would therefore not be related to the individuals that they wintered and subsequently paired with, and their introduction into local populations would have a homogenizing effect on population structure similar to winter dispersal. Presently there is no genetic evidence for fine scale differentiation in Harlequin Ducks (Brown 1998, Lanctot et al. 1999), but at a broader scale there is (K. Scribner unpubl., in Robertson and Goudie 1999). Research on winter movements of individuals and on frequencies of true versus adoptive families is required to determine the degree to which family migration could lead to population differentiation and to demographically closed populations.

Harlequin Ducks (at least the Pacific population) are unlike most species of ducks in that they often molt and winter in the same location (Breault and Savard 1999 Robertson et al. 1999), and this difference may allow Harlequin Duck juveniles to migrate with their mothers. Molting sites for females are not specific habitats close to breeding areas as they are in some duck species (Hohman et al. 1992), where an extended family bond could represent a fitness cost to both the flightless mother and her young. In Harlequin Ducks, both females and offspring could benefit from family migration because offspring would reach a successful wintering location and females would improve their own fitness if the survival of their offspring were enhanced.

To our knowledge the evidence we provide is the first suggesting that female migratory ducks bring their offspring to wintering areas, a pattern that is well known in geese and swans. Such evidence is extremely difficult to obtain by traditional methods of study. Although there are several studies that provide convincing evidence of brood abandonment prior to fledging (Joyner 1977, Pöysä et al. 1997), it may be difficult to detect cases where families stay together. For example, permanent abandonment may be confused with temporary absences (Ball et al. 1975) or mortality of the female. Thus in many species the precise time of brood abandonment is not known, and often it is simply assumed to occur at fledging. With the development of satellite technology, it should be possible to investigate this question more thoroughly and in a wider range of species.

We are grateful to Michael Rodway, Ken Wright, Rachel Botting, and Pete Clarkson for assistance with capture of family groups in wintering areas and for donating behavioral data. We thank Jesse Whittington, Drs. Todd Shury and Malcolm McAdie, and numerous volunteers for assistance on the breeding streams. Many thanks to Dan Esler and Jean-Pierre Savard, whose critical reviews substantially improved the manuscript. Funding was provided by NSERC of Canada, Centre for Wildlife Ecology, Simon Fraser University, Alberta Environmental Protection, Aquatics Section of the Lake Louise/Yoho/Kootenay Business Unit of Parks Canada, the Biodiversity Grants Program (Department of Biological Sciences, University of Alberta, through joint efforts of the sportsmen of Alberta and the Alberta Department of Environmental Protection, Fish and Wildlife Trust Fund), British Columbia Waterfowl Society, Institute of Waterfowl and Wetlands Research (IWWR), Canadian Wildlife Service, and Parks Canada Highway Services.

\section{LITERATURE CITED}

Afton, A. D., AND S. L. Paulus. 1992. Incubation and brood care, p. 62-108. In B. D. J. Batt, A. D. Afton, M. G. Anderson, C. D. Ankney, D. H. Johnson, J. A. Kadlec, and G. L. Krapu [EDS.], Ecology and management of breeding waterfowl. University of Minnesota Press, Minneapolis, MN.

Anderson, M. G., J. M. RhyMer, ANd F. C. RoHwER. 1992. Philopatry, dispersal and the genetic structure of waterfowl populations, p. 365-395. In B. D. J. Batt, A. D. Afton, M. G. Anderson, C. D. Ankney, D. H. Johnson, J. A. Kadlec, and G. L. Krapu [EDS.], Ecology and management of breeding waterfowl. University of Minnesota Press, Minneapolis, MN.

Ball, I. J., D. S. Gilmer, L. M. Cowardin, AND J. H. REICHMANN. 1975. Survival of wood duck and mallard broods in north-central Minnesota. Journal of Wildlife Management 39:776-780.

Bengtson, S.-A. 1966. Field studies on the Harlequin Duck in Iceland. Wildfowl 17:79-94.

Breault, A., AND J.-P. L. Savard. 1999. Philopatry of Harlequin Ducks moulting in southern British Columbia, p. 41-44. In R. I. Goudie, M. R. Petersen, and G. J. Robertson [EDS.], Behaviour and ecology of sea ducks. Occasional Paper No. 100, Canadian Wildlife Service, Ottawa, Canada.

Brown, M. E. 1998. Population genetic structure, kinship, and social associations in three Harlequin Duck (Histrionicus histrionicus) breeding subpopulations. M.Sc. thesis, University of California, Davis, CA.

CARLISLE, T. R. 1982. Brood success in variable environments: implications for parental care allocation. Animal Behaviour 30:824-836. 
Cassirer, E. F., AND C. R. Groves. 1991. Harlequin Duck ecology in Idaho: 1987-1990. Idaho Department of Fish and Game, Boise, ID.

Cooke, F., G. J. Robertson, C. M. SMith, R. I. GouDIE, AND W. S. BOYD. 2000. Survival, emigration, and winter population structure of Harlequin Ducks. Condor 102:137-144.

Diamond, S., AND P. Finnegan. 1993. Harlequin Duck ecology on Montana's Rocky Mountain Front. USDA Forest Service, Rocky Mountain District, Lewis and Clark National Forest, Choteau, MT.

EAdIE, J. M., M. L. Mallory, AND H. G. LumSDEN. 1995. Common Goldeneye. In A. Poole and F. Gill [EDS.], The birds of North America, No. 170. The Academy of Natural Sciences, Philadelphia, and The American Ornithologists' Union, Washington, DC.

Hohman, W. L., C. D. Ankney, and D. H. Gordon. 1992. Ecology and management of postbreeding waterfowl, p. 128-189. In B. D. J. Batt, A. D. Afton, M. G. Anderson, C. D. Ankney, D. H. Johnson, J. A. Kadlec, and G. L. Krapu [EDS.], Ecology and management of breeding waterfowl. University of Minnesota Press, Minneapolis, MN.

JoYNER, D. E. 1977. Behavior of Ruddy Duck broods in Utah. Auk 94:343-349.

KuCHEL, C. R. 1977. Some aspects of the behavior and ecology of Harlequin Ducks breeding in Glacier National Park, Montana. M.Sc. thesis, University of Montana, Missoula, MT.

LANCtot, R., B. GoATChER, K. Scribner, S. TAlbot, B. PIERSON, D. EsLER, AND D. ZWIEFElHofer. 1999. Harlequin Duck recovery from the Exxon Valdez oil spill: a population genetics perspective. Auk 116:781-791.

MalloRy, M., AND K. Metz. 1999. Common merganser (Mergus merganser). In A. Poole and F. Gill
[EDS.], The birds of North America, No. 442. The Birds of North America, Inc., Philadelphia, PA.

Pöysä, H., J. VIRTANEN, AND M. MILONOFF. 1997. Common Goldeneyes adjust maternal effort in relation to prior brood success and not current brood size. Behavioral Ecology and Sociobiology 40:101-106.

PrevetT, J. P., AND C. D. MacInNes. 1980. Family and other social groups in Snow Geese. Wildlife Monographs 71:1-46.

Reichel, J. D., D. L. Genter, AND D. P. Hendricks. 1997. Harlequin Duck research and monitoring in Montana: 1996. Montana Natural Heritage Program, Helena, MT.

RoBERTSON, G. J., AND R. I. GoudIE. 1999. Harlequin Duck (Histrionicus histrionicus). In A. Poole and F. Gill [EDS.], The birds of North America, No. 466. The Birds of North America, Inc., Philadelphia, PA.

Robertson, G. J., F. COOKE, R. I. Goudie, AND W. S. BOYD. 1999. Within-year fidelity of Harlequin Ducks to a moulting and wintering area, p. 4551. In R. I. Goudie, M. R. Petersen, and G. J. Robertson [EDS.], Behaviour and ecology of sea ducks. Occasional Paper No. 100, Canadian Wildlife Service, Ottawa, Canada.

Rodway, M. S., J. W. Gosse JR., I. FonG, AND W. A. MoNTEVECCHI. 1998. Discovery of a Harlequin Duck nest in eastern North America. Wilson Bulletin 110:282-285.

SMith, C. M. 2000. Survival and recruitment of juvenile Harlequin Ducks. M.Sc. thesis, Simon Fraser University, Burnaby, British Columbia, Canada.

Smith, C. M., F. CoOke, G. J. Robertson, R. I. GouDIE, AND W. S. BoYD. 2000. Long-term pair bonds in Harlequin Ducks. Condor 102:201-205.

WALLEN, R. L. 1987. Habitat utilization by Harlequin Ducks in Grand Teton National Park. M.Sc. thesis, Montana State University, Bozeman, MT.

\title{
THE SOCIAL ORGANIZATION AND MATING SYSTEM OF THE STRIATED GRASSWREN ${ }^{1}$
}

\author{
JORDAN KARUBIAN ${ }^{2}$ \\ Department of Ecology and Evolution, University of Chicago, 1101 E. 57th St., Chicago, IL 60637
}

\footnotetext{
Abstract. This paper summarizes the breeding biology, social organization, and mating system of the Striated Grasswren (Amytornis striatus), a member of

${ }^{1}$ Received 17 June 2000. Accepted 18 December 2000.

${ }^{2}$ E-mail: jordan@uchicago.edu
}

one of the least-known genera of Australian passerines, the grasswrens. I studied 18 color-banded groups and 14 nests in South Australia for one breeding season in 1996. Mean territory size was 3.0 ha, and territories consisted of sandy dunes dominated by spinifex (Triodea irritans). This apparent dependency on mature spinifex, coupled with poor dispersal ability, suggests that the Striated Grasswren is particularly susceptible 